\title{
DYSKRETNY UROK KONTRKULTURY
}

Patrząc z dzisiejszej perspektywy na „piękne i odległe” lata 60., wolno zasadnie twierdzić, że w politycznym wymiarze sfery publicznej kontrkultura zdziałała niewiele, nie zdołała zachwiać utrwalonym ładem instytucjonalnym ani go przekształcić, chociaż przeciwko niemu się buntowała. Wreszcie to, co decydowało o specyfice kontrkultury jako ruchu radykalnego sprzeciwu wobec społeczno-kulturowego mainstreamu lat 70., przeszło obecnie w obszar dyskursu kultury masowej, a sam bunt został skanalizowany i wchłonięty przez struktury korporacyjnego kapitalizmu. Co w takim razie zostało nam z dziedzictwa kontrkultury, czy posiada ona jeszcze jakiś, choćby symboliczny potencjał, ożywczy impuls, niewyschnięte źródlisko? Być może da się uzasadnić, dlaczego jej potrzebujemy, jako jednej z kilku ważnych dwudziestowiecznych ideologii, rozumianych jako reprezentacja roszczeń grup społecznych do posiadania ponadindywidualnych interesów. Próbę taką podejmuje w swoim artykule, będącym rozbudowanym komentarzem do klasycznej książki Theodore’a Roszaka, Michał Kaczmarczyk. Doświadczenia radykalnych rozłamów kulturowych zawsze niosą ryzyko nowego barbarzyństwa, ale czy groźba powrotu rozsierdzonych Centaurów jest realna? Obawy te próbuje rozwiewać w klasycznej już dla badań nad kontrkulturą książce Theodore Roszak - tłumaczenie jednego z jej rozdziałów otwiera ten numer. Doświadczenie zaleca tutaj jednak rozsądną ostrożność, bo konsekwencje buntów i rewolucji to często ,stare zbrodnie świata [...] nowym kołujące tańcem”.

W kulturze hiperindywidualizmu wszyscy ci, którzy nie uczestniczą w wyścigu szczurów i nie poświęcają się pracy ponad siły, zarabianiu pieniędzy oraz konsumpcji na pokaz, stają się wykluczonymi. Można postawić zatem pytanie, czy nie nadszedł czas spontanicznej mobilizacji społecznej przeciwko panoszącej się kulturze konsumpcji, czy nie mamy sprzyjającego nowej kontrkulturze klimatu przesytu i buntu przeciwko życiu zgodnemu z imperatywami, de facto neurozami, rynku; klimatu, któremu towarzyszy refleksja, że to życie zmarnowane. Czy możemy w tym wypadku mówić o wyraźnej kulturowej tendencji do ograniczania konsumpcji oraz krytyki materialistycznej orientacji życiowej (zastanawia się nad 
tym Andrzej Kasperek, analizując przypadek minimalizmu). Jeśli wobec współczesnego kryzysu, nasilającego się poczucia niepewności i utraty bezpieczeństwa postawimy sobie zasadnicze pytanie o to, czy powinniśmy uelastyczniać siebie, czy rekonstruować system, to otrzymamy dylemat: czy dostosowywać się do restrukturyzującego się kapitalizmu, czy humanizować sam kapitalizm, przystosowywać go do ludzkich miar. Pierwszy przypadek zakłada, że człowiek jest wiązką ekonomicznych współzależności, Frommowskim „charakterem merkantylnym”. Tym samym najbardziej owocna płaszczyzną analizy relacji pomiędzy środowiskiem człowieka a kapitalistyczną infrastrukturą stają się kategorie użyteczności i racjonalności instrumentalnej, na których wspiera się gmach socjologii Weberowskiej. W drugim przypadku możliwa do pomyślenia jest kolejna kontrkulturowa rewolucja, rozumiana jako wcielenie starych idei radykalnego humanizmu. Pytanie tylko, czy podejmowane ostatnimi czasy próby wskrzeszania kontrkulturowej duchowości mogą stanowić remedium na deficyt myślenia, czy są wyrazem autentycznej potrzeby sensu, stanowiącej rezultat pracy świadomości mitycznej w rozumieniu Leszka Kołakowskiego, czy też mamy tutaj do czynienia z kolejną modą i strategią adaptacyjną w ramach kultury indywidualizmu.

Kontrkultura jako bunt polityczny, świetnie zobrazowany przez Milana Kunderę w Nięnośnej lekkości bytu, przyczyniła się w istocie do erozji politycznego zaangażowania. Nieco prowokacyjna insynuacja, że przedstawiciele kontrkultury nie byli $\mathrm{w}$ istocie nigdy zainteresowani realizacją celów politycznych, a jedynie buntem w sferze symbolicznej, można by skłonić do bardziej rzeczowej analizy dziedzictwa kontrkultury współcześnie. Zmiana systemu dla wielu osób z pokolenia '68 zaczynać się musi od zmian kulturowych, a te sa przeobrażeniami świadomości ludzkiej. W konsekwencji polityka kulturowa staje się ważniejsza niż polityka redystrybucji, dążąca do sprawiedliwego podziału dóbr. Zainteresowania przedstawicieli klasycznej kontrkultury szeroko pojętą duchowością przełożyły się na poszukiwania holistycznych paradygmatów, podczas gdy współcześnie kultura indywidualizmu hołduje raczej indywidualistycznemu egoizmowi, ewoluując w stronę mikrowspólnot smaku. Nad sygnalizowanymi powyżej problemami (i nie tylko) zastanawiają się publikujący w tym numerze autorzy.

Szeroko dyskutowane ostatnimi czasy przez rozmaitych badaczy społecznych poczucie zagrożenia, niepewności i niezadowolenia przestaje być współcześnie doświadczeniem mniejszości, jak w 1968 roku, stając się doświadczeniem większości - to radykalna zmiana. O ile w latach 70. buntowano się przeciwko pokoleniu rodziców, o tyle obecnie daje się wyczuć nostalgię za tamtymi czasami - w Europie Zachodniej był to czas prosperity 
i pewności. Chociaż młodsze pokolenia niewątpliwie tęsknią za pewną praca, to jednak wyłącznie w pakiecie ze wszystkimi dobrodziejstwami, które zawdzięczamy kontrkulturze: $z$ rewolucją seksualną i technologiczną, prawami mniejszości, feminizmem trzeciej fali, równouprawnieniem itd. Można zaryzykować tezę, że wokół konfliktu pokoleń toczyć się będzie współcześnie spór o to, czym jest sprawiedliwość społeczna. Jest to, jak wiadomo, fundamentalne zagadnienie z zakresu filozofii politycznej. Można odgadywać kontury tego sporu w pojawiających się wątpliwościach, czy system demokratyczny będzie w niedalekiej przyszłości korzystny dla młodego pokolenia, które znajdzie się w mniejszości w wyniku nieubłaganych procesów demograficznych, czyli starzenia się społeczeństw. $\mathrm{Na}$ tym tle zgoła inaczej prezentuje się konflikt pokoleniowy z lat 60., który miał swoje podłoże moralne, a jednocześnie rozgrywał się w obliczu sporu o obowiązujące normy kulturowe. Początkowo były to pozornie błahe kwestie estetyczne dotyczące dobrego smaku, którego młodzi radykałowie odmawiali „wapniakom i sztywniakom”, czyli pokoleniu swoich rodziców, podczas gdy sami uważali się za przebojowych „luzaków”. Spoglądając na ów generacyjny konflikt z perspektywy czasu, trudno oprzeć się wrażeniu, że jego źródła tkwiły przede wszystkim w kulturze popularnej, zwłaszcza w muzyce (rock), filmie (francuska Nowa Fala) i literaturze (Kerouac, Ginsberg). Z drugiej strony, paradoksalnie, w Europie Zachodniej powszechnie podzielano odrazę do amerykańskiego imperializmu, posuwając się nawet do porównań z faszyzmem. Inaczej mówiąc, zgeneralizowanej niechęci do Ameryki towarzyszyło niebywałe zainteresowanie jej kultura popularna. Taka hipokryzja cechowała nawet francuskich sytuacjonistów, którzy z rozmachem czerpali z inkryminowanych form masowej kultury. Trudno jednoznacznie ocenić fenomen niezwykłej atrakcyjności amerykańskiej popkultury oraz jej wpływu na kontrkulturę, ale z pewnością stanowiła ona podstawowe narzędzie kształtowania wśród pokolenia '68 wyobrażeń o seksie i relacjach między mężczyznami i kobietami, co wpłynęło na kształt rewolucji obyczajowej po obu stronach oceanu. Nasuwa się tutaj ogólnokulturowa refleksja, że widoczny dysonans między silnie nasyconą seksualnością kulturą amerykańską lat 50. i 60. a restrykcyjnymi agendami socjalizacji pierwotnej i wtórnej, domu i szkoły, wywoływać musiał szczególny rodzaj napięcia. Napięcie między oficjalnymi wartościami, zarówno świeckimi, jak i tymi oferowanymi przez religie, a kulturą codzienności, w której dominowały seks, bunt, muzyka rockowa oraz używki, musiało zostać jakoś rozwiązane - analiza fenomenu kontrkultury pomaga wyjaśnić, w jaki sposób.

Tomasz Maślanka 